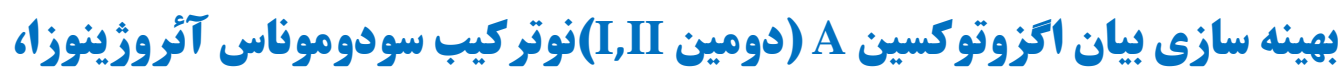 تخليص و ارزيابى آن در آزمايشكاه
}

\author{
ليدا افتخارى وش'، صفر فرج نيا'، شهين نجار بيرايه'، اصغر تنومند
}

'مربى ميكروبيولوزى، كروه ميكروبيولوزى، دانشكاه آزاد اسلامى واحد مراغه، مراغه، ايران

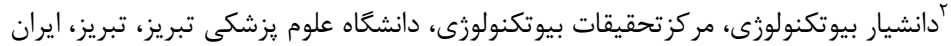

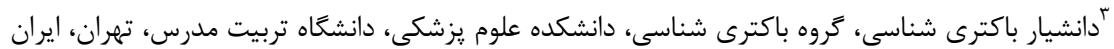

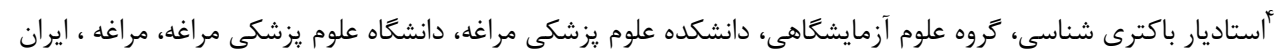

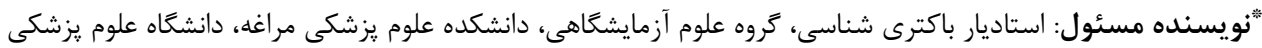

مراغه، مراغه، ايران tanomanda@yahoo.com : يست الكترونيك مراغه، إن

جكيده

زمينه و هدف:اتزوتوكسين A فاكتور مهم در بيماريزايى سودوموناس آئروزينوزا بوده وخنثى سازى آن در

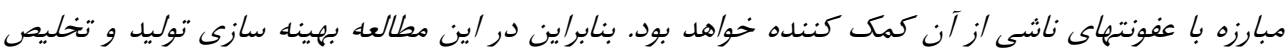

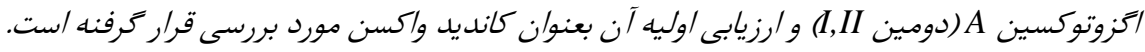

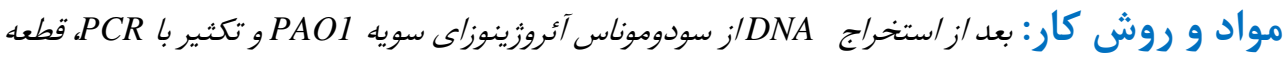

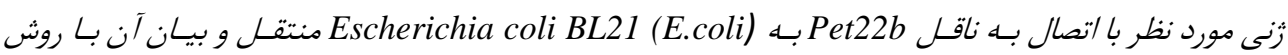

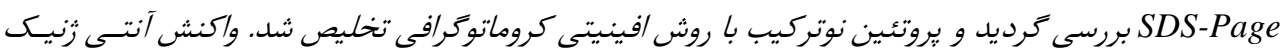

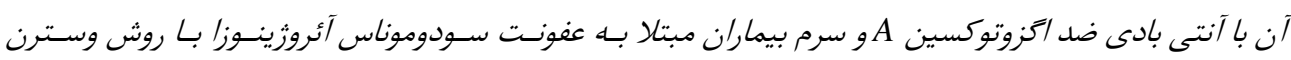
بلاتينََ بررسى كرديد.

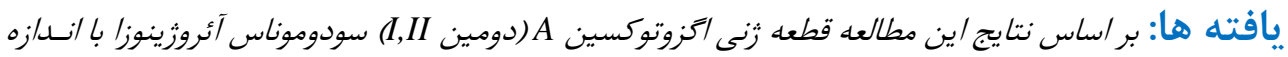

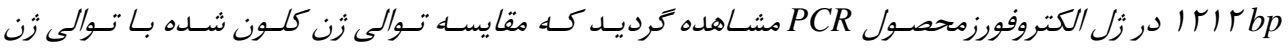

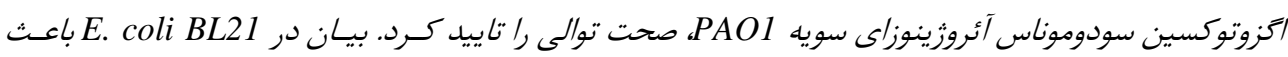

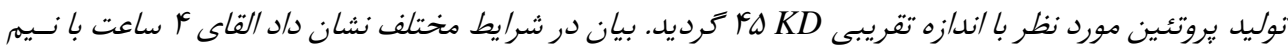

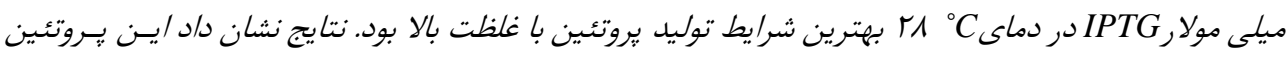

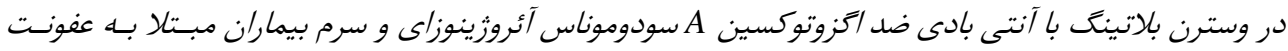

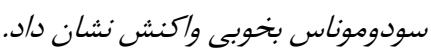

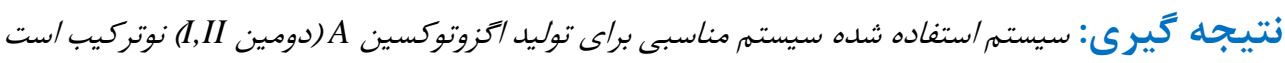

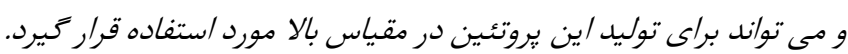

وصول:

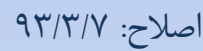

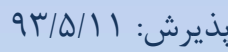

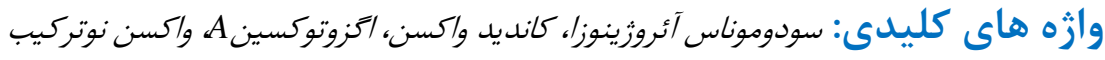


ييشكيرى براى عفونتهاى سودوموناس مطرح شد تحقيقات

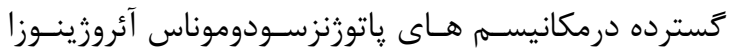
منجر به معرفى فاكتورهاى بيماريزاى بـاكترى شــده و بــر

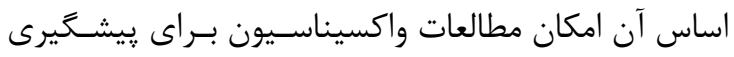

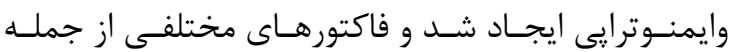
ليــويلى سـاكاريد-اگزوتوكسـين A - ريبـوزوم- فـلازل-

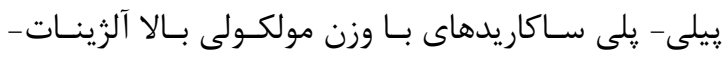

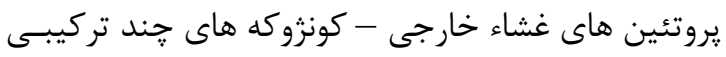
و واكسن ها - يروتئين هاى سيستم ترشحى DIII DNA-

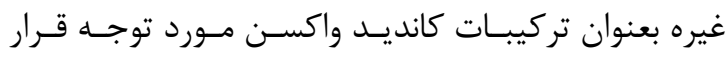

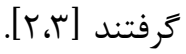
در ميان توكسينهاى خارج سلولى سودوموناس آئروزينوزا، اكزوتوكسين A نقش مهمى در بيماريزاى دارد. بررسيها

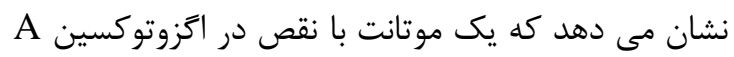
• آبار بيماريزاى كمترى نسبت به سويه وحشى در موشها

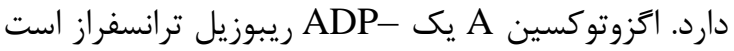

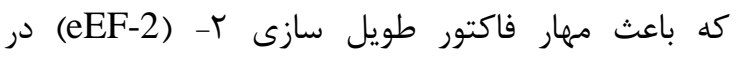
سلولهاى يوكاريوت مى شود، در نتيجه سنتز بروتئين مهار شده و سلول مى ميرد. اگزوتوكسين A باعث مهار ياسخ

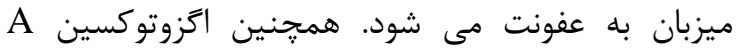

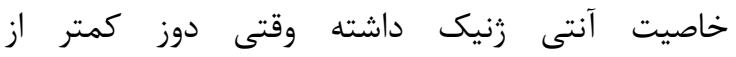
سيتوتوكسيك آن به كار مى رود برعليه آن آنتى بادى داصيك

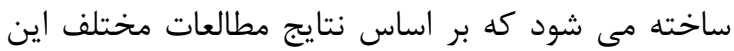

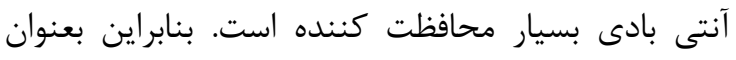

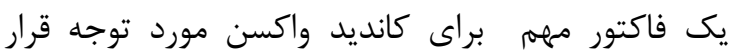

$$
\text { كرفت [4-9] }
$$

زنجير يلى يُّتيدى اكزوتوكسين A براساس عملكرد سه

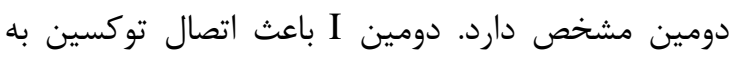
سلول هدف مى شود كه خود به دو دومين كوجى تقسيم

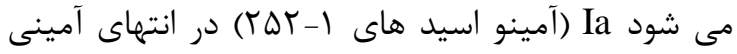

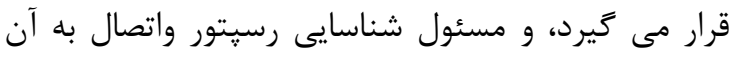

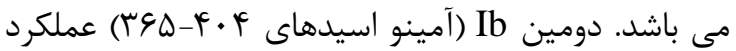
دقيق آن مشخص نيست ممكن است براى ترشح توكسين ضرورى باشد و يا در سميت نقش كمكى داشته باشد.

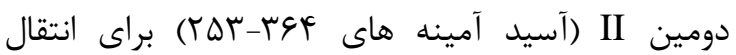

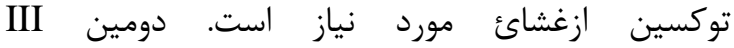

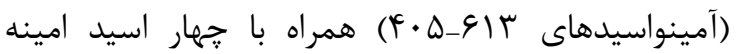

سودوموناس آئروزينوزابه طور رايج از عفونت هاى

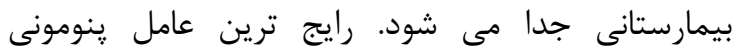

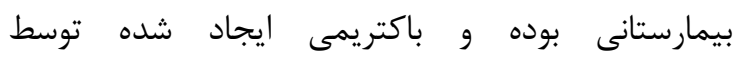
سودوموناس آئروزينوزا داراى مرى و مير بالاى مى باشد. سودوموناس آئروزينوزا در دستگاه تنفسى تطابق خوبى آريى ايجاد كرده است. اين تطابق بخصوص در درو بيماران

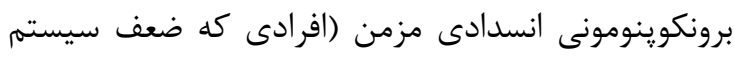
ايمنى دارند و در بخش مراقبت هاى ويزه بسترى مى آنى

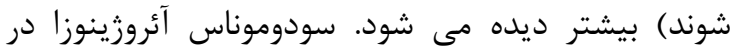

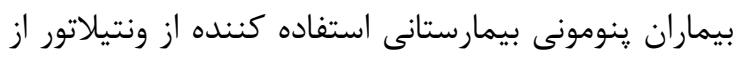

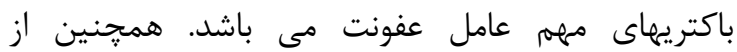
مهمترين عوامل عفونت ريوى در بيماران سيستيك

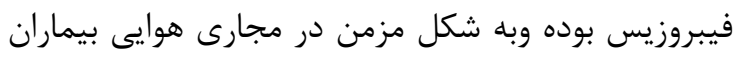

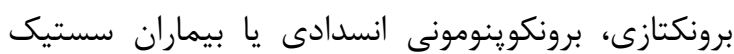
فيبروزيس هم وجود دارد و در بيماران سرطانى نوتروينك برون

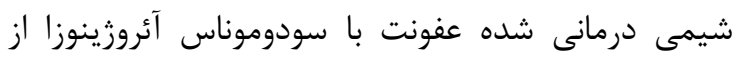

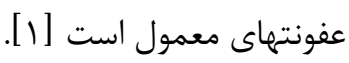
سودوموناس آئروزينوزا فاكتورهاى بيماريزاى متعددى دارد كه نشان دهنده ماهيت بيماريزايى بيجيديده آن اسـت، هـر

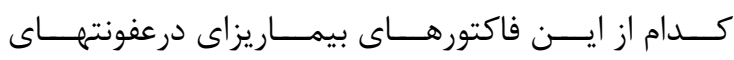

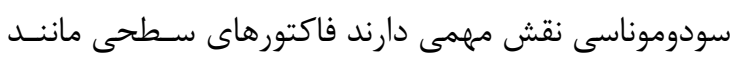

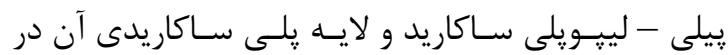

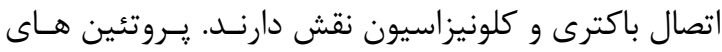

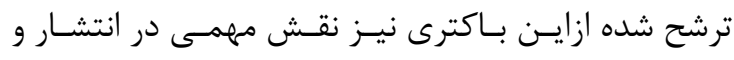

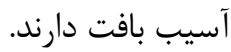

با مصرف گسترده ينى سـيلين و سـاير آنتسى بيوتيـك هـا

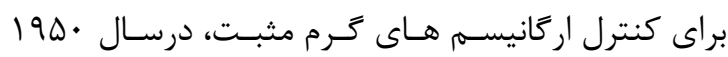
باكترهاى حـرم منفـى بخصـوص سـودوموناس آئروزينـوزا بعنوان عوامل ايجاد كننده عفونت در جمعيت انسانى خود

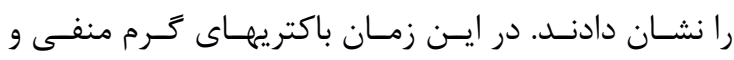

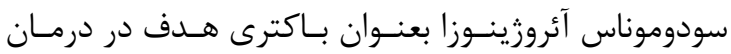

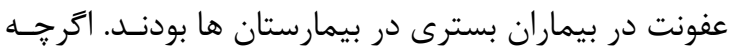

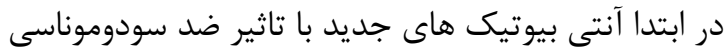
در كنترول سودوموناس آئروزينوزا موفق بودند اما استعداد

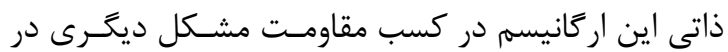

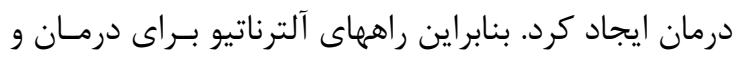




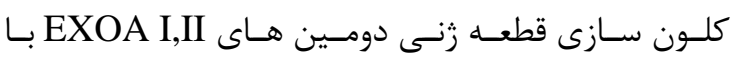
استفاده از وكتور PTZ57R، ميزبان ع.Coli DH5 و بـاــان روش TNS براساس دسـتور العمل كيـت T/A Cloning أنجام شد. براى غربـالكرى كلونهاى حاوى ناقل نوتركيب PTZ57R-ExoA تعدادى از كلنى هاى سفيد رنك رشد يافتـه در محسيط LB آتَار

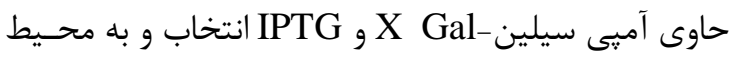

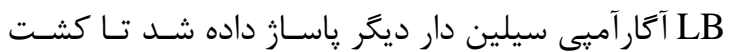

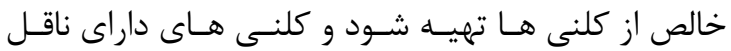
نوتر كيـب PTZ57R-ExoA بـا روشهــاى انجـام PCR، هضم آنزيمسى و تعيسين تـوالى از طريـق شـركت MWG

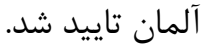

PTZ57R- براى ساب كلونينگ ابتدا پِلاسـميد نوتركيـبـ ExoA

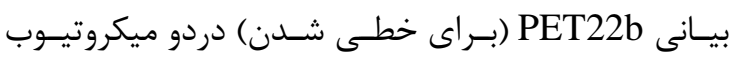

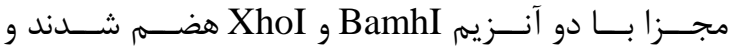

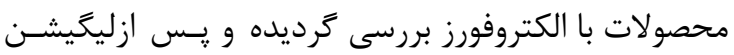

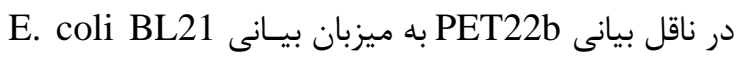
SDS- ترنسفورم شد. جهت بررسى بيان ي-روتئين از روش Sodium Dodecyl Sulphate-) PAGE (Polyacrylamide Gel Electrophoresis براى اين كار ازكلونىهاى تاييد شده، كلونى تك انتخـاب و

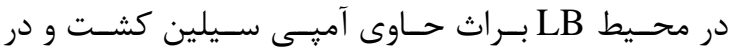

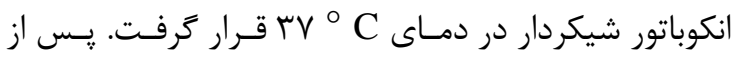

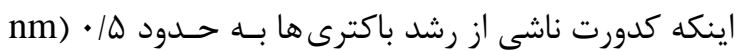

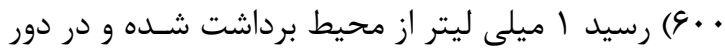

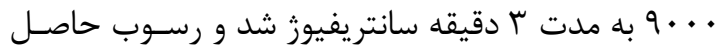
بعنوان نمونه القاء نشده جمع آورى كرديد. به بـاقى مانـده محيط كشت IPTG با غلظت ا ميلى مولار اضـافه شـد و مجدداً انكوباسيون محيط القاء شده تا دو ساعت ادامه بيدا

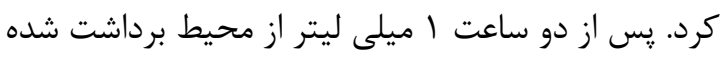

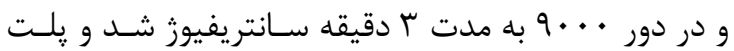

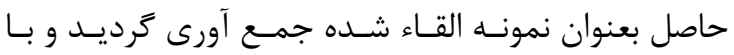
استفاده از SDS-PAGE ميزان بيان بررسى كرديد. بـراى

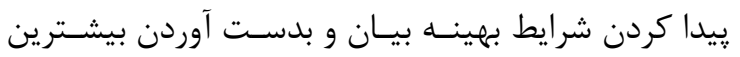

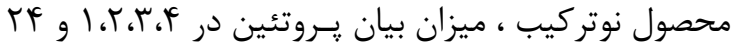

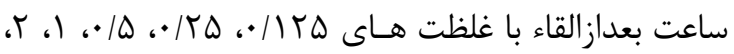

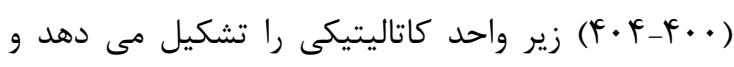
فعاليت ADP- ريبوزيل ترانسفرازى دارد. اين عمل منجر

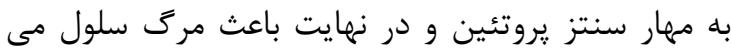

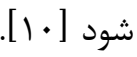
براى تزريق به حيوان آزمايشًاهى و مطالعه آثارحفاظتى اتزوتوكسين A غيرسمى، تهيه و تخليص آن، اولين قدم آنمابقان

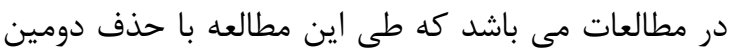

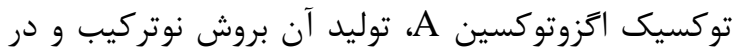
شرايط بهينه با غلظت بالا و نتايج ارزيابى خصوصيات آنتى زنيك آن درآزمايشعاه كزارش شده است.

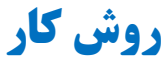
ابتدا يك جفت يرايمر براى دومين هاى I و II I احيه

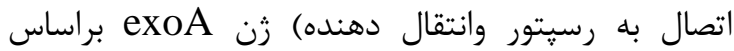

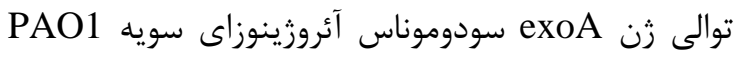

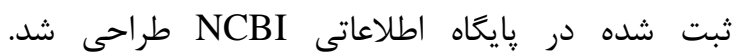
يرايمرهاى طراحى شده با نرم افزار

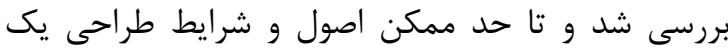
يرايمر مناسب همانندعدم ايجاد لوٍ، دايمر، سنجاق سر،

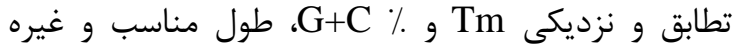

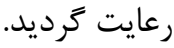

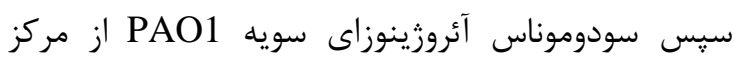
تحقيقات بيوتكنولوزى دانشكاه علوم يزشكى تبريز تهيه و يس از كشت واحياء با استفاده از تست هاى متداول

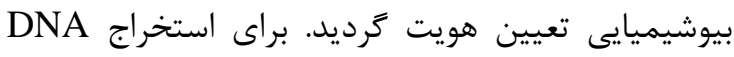

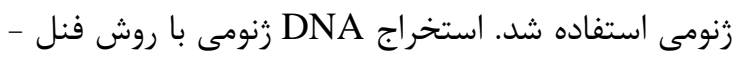
كلروفرم صورت كرفته و كميت و كيفيت DNA استخراج شده با استفاده از روش هاى اندازه كيرى جذب نورئ نورى در

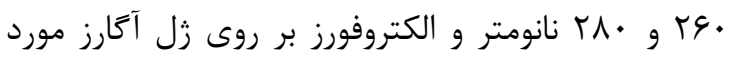

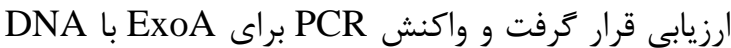
رنومى در حجم براى جداسازى و تخليص ExoA از ساير باندهاى غير اختصاصى احتمالى و جذف رئ يرايمرهاى باقى مانده، محصول PCR بر روى زل آكارز الكتروفورز و سيس بانيس باند

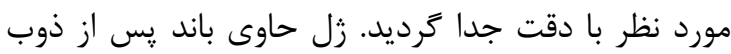

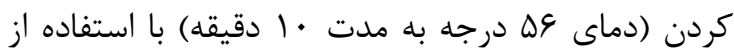
كيت تخليص از زل MN (Macherey Nagel) دستورالعمل شركت سازنده بازيافت و خالص شد. 


\begin{tabular}{|c|c|}
\hline \multicolumn{2}{|c|}{ جدول ا: تنظيم دمايى دستگاه ترموسايكلر } \\
\hline primery Denaturation & 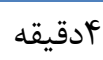 \\
\hline secondary Denaturation & دقيقه \\
\hline Annealing & دقيقه \\
\hline Primery Extention & دقيقه \\
\hline secondary Extention & دقيقه \\
\hline & \\
\hline
\end{tabular}

سانتريفوز شد تا ناخالصى هـاى آن رسـوب كنــد و مـايع رويى براى انجام كروماتوخرافى آماده كردد.

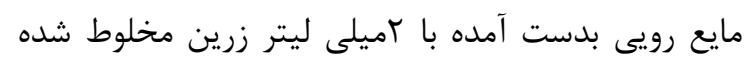

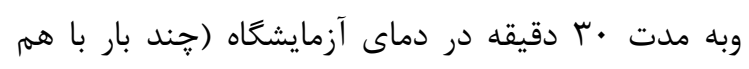

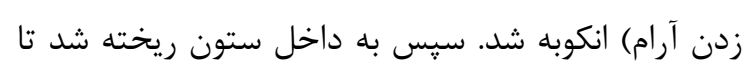

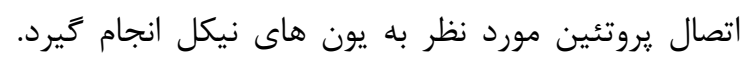

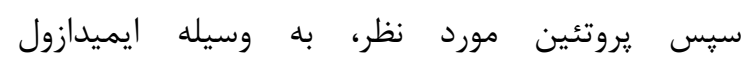
(Imidazole)

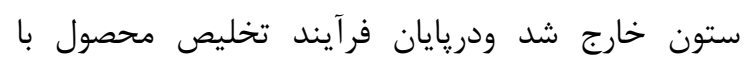
SDS-PAGE

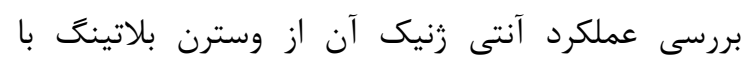

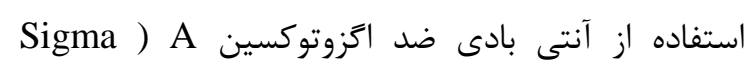

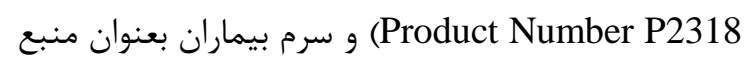
آنتى بادى بطور جداكانه استفاده شد.

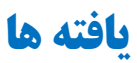

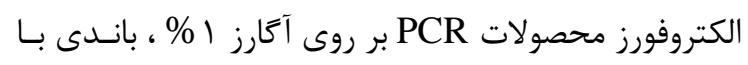

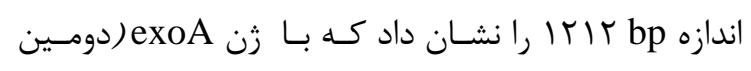
(I,II داشت (شكل (1).

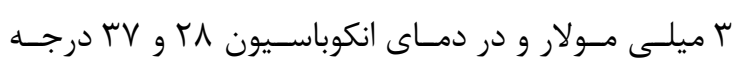
سانتيكراد بررسى كرديد. براى بررسى محلول بودن ويا انگلورن بادى بودن يروتئين،

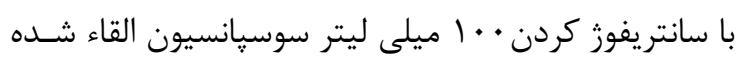

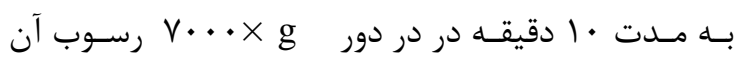

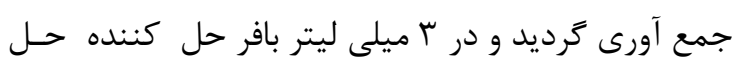

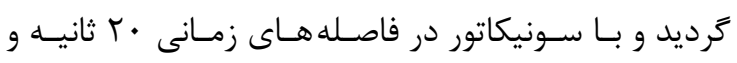

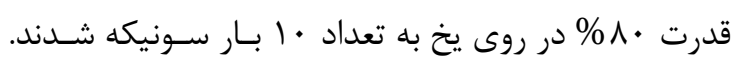

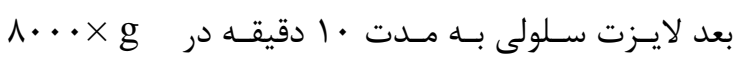

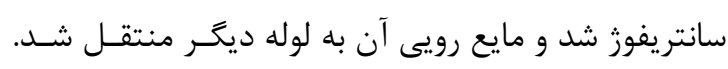

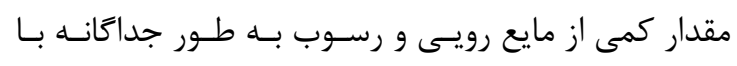

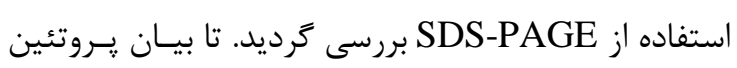
به صورت محلول ويا انكلوزن بادى مشخص كر كردد.

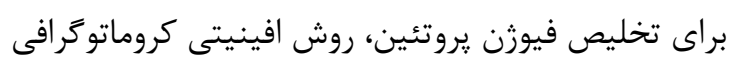

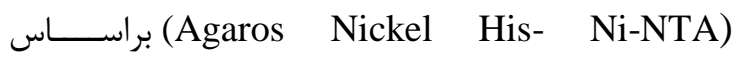
دستورالعمل كيت ساخت شركت QIAGEN استفاده شد. رسوب بدست آمده از محصول سونيكاسيون جندين باخت بار در

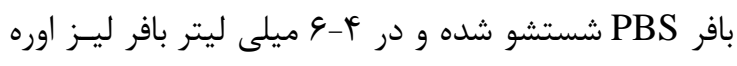

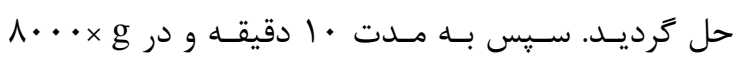



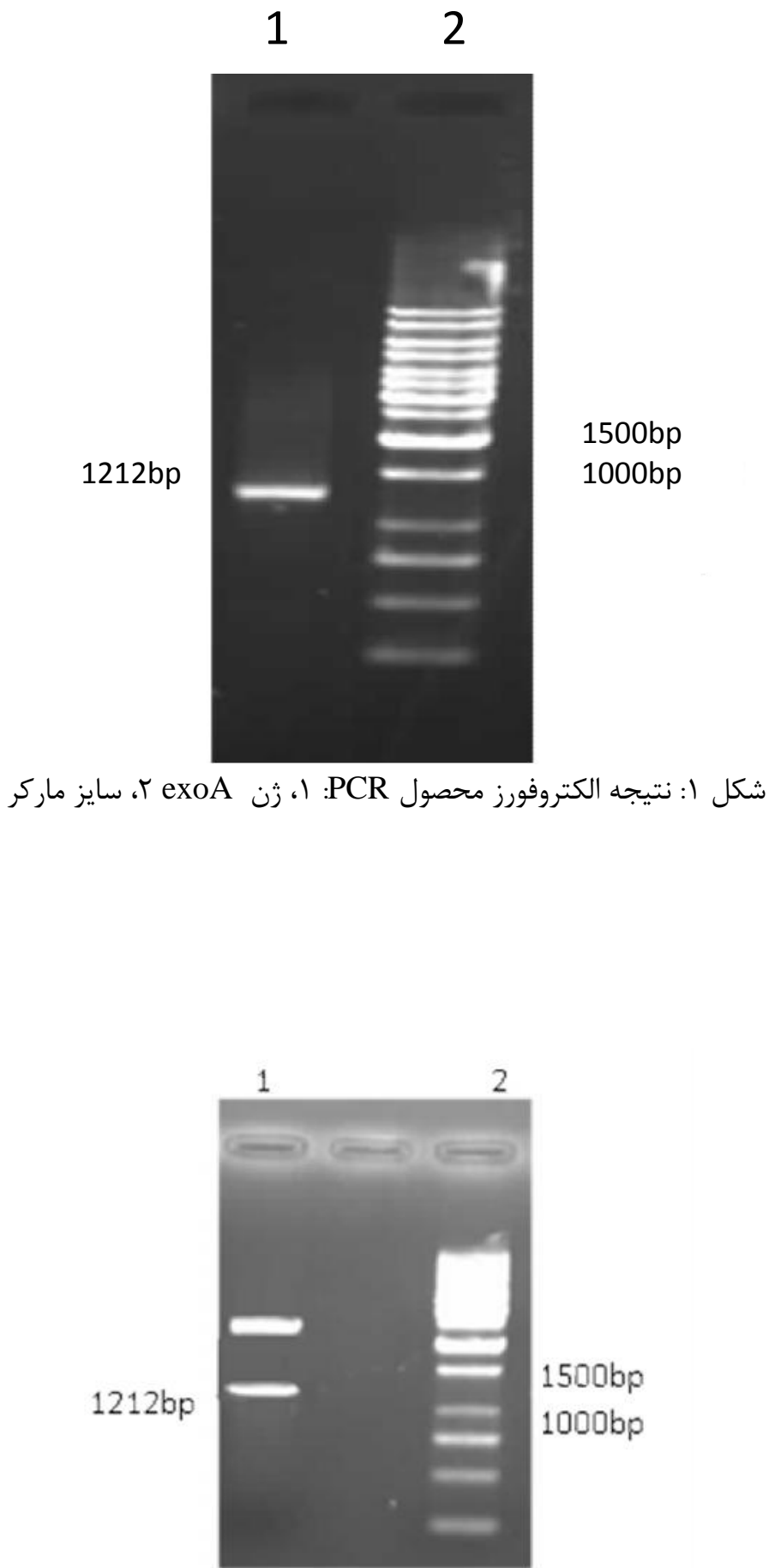

شكل r: الكتروفورز محصول هضم آنزيمى ناقل نوتر كيب PET22b-ExoA با آنزيمهاى BeAoAII و ExoAI,II -1,Xho I 

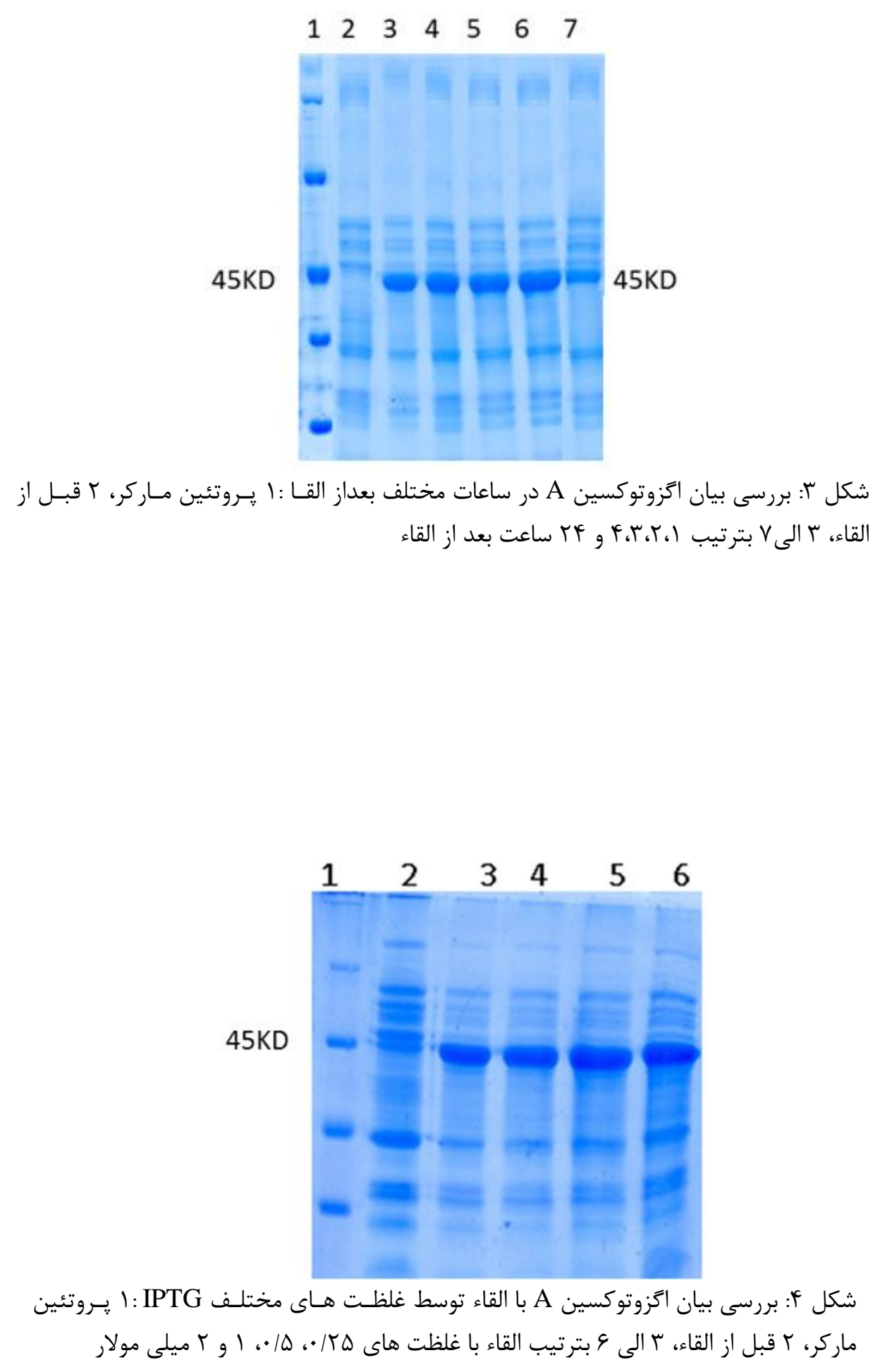


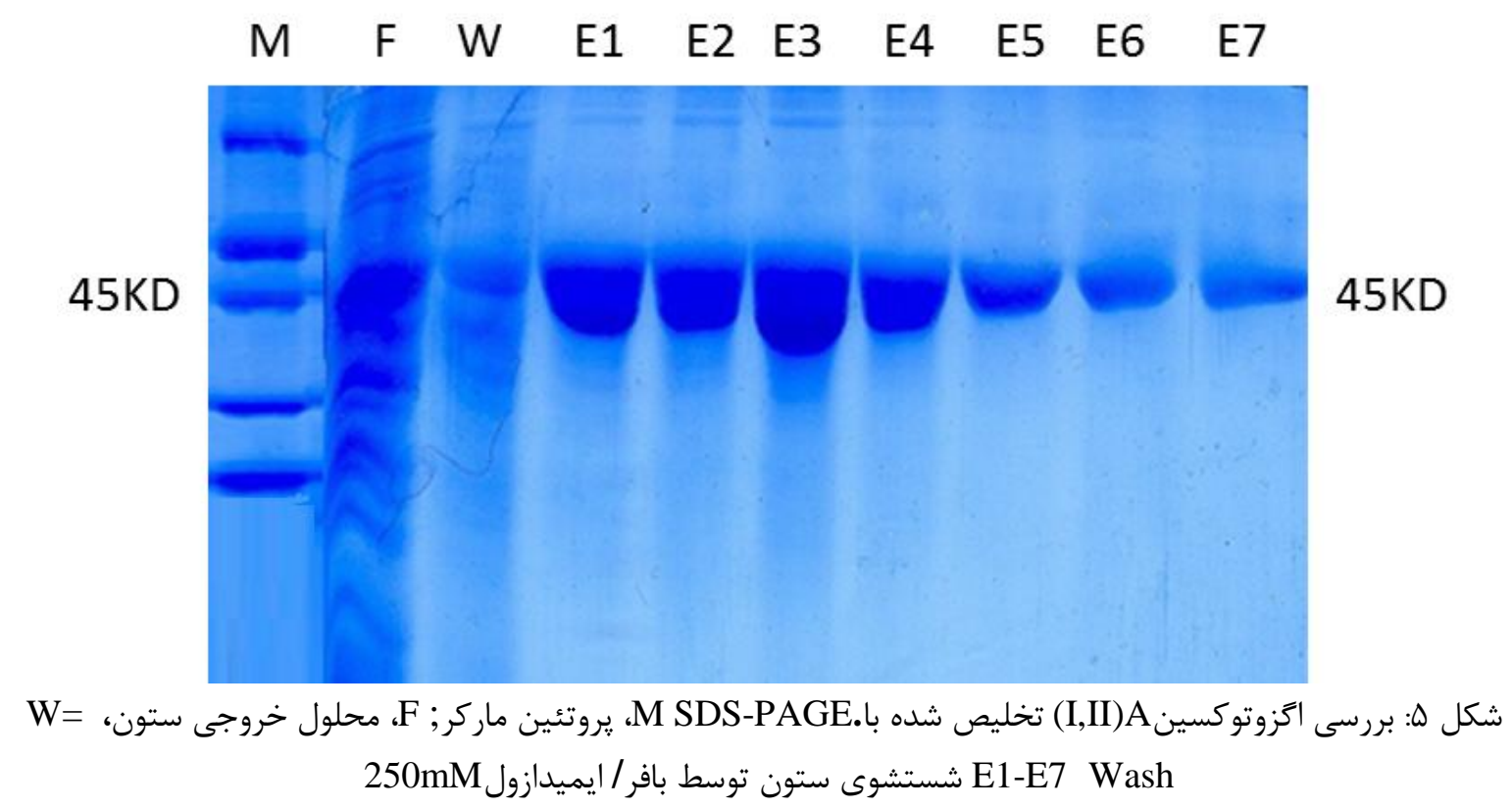

$1 \quad 2 \quad 3 \quad 4$

شكل \&: نتايج ايمونوبلاتينگ با استفاده از آنتى بادى اكزوتوكسين A و سرم بيماران مبتلا به عفونت سودوموناس آئروزينوزا

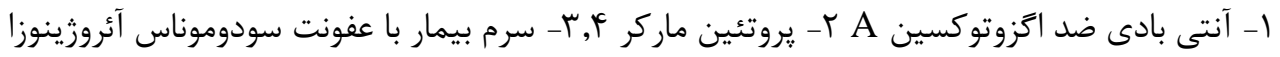


باكترى همجنين داراى تعداد زيادى از فاكتورهاى مقاومت

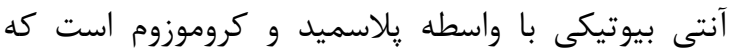

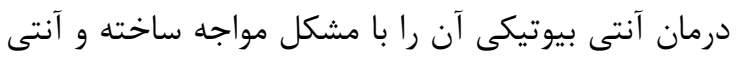

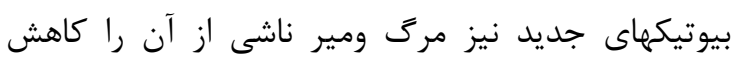

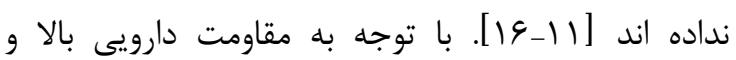

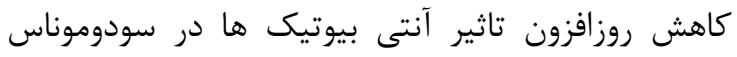

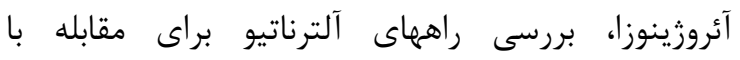

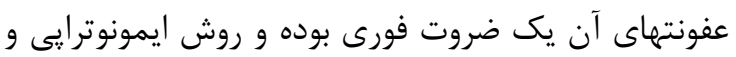
ايمونويروفيلاكسى مى تواند يكى از موثرترين راهها باشد

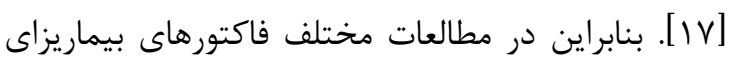
متعدد بعنوان كانديد واكسن مورد توجه قرار كرفته است درئ

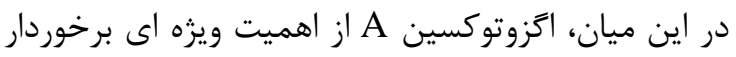

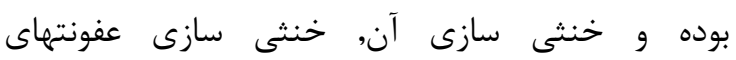

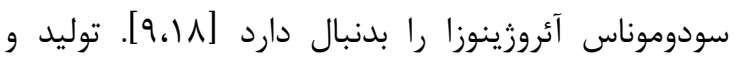
تخليص اتزوتوكسين A با روشهاى مختلف و ارزيابى آن بعنوان كانديد واكسن در مطالعات مختلف كزارش شدهائ

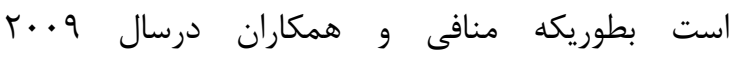

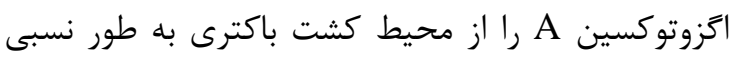

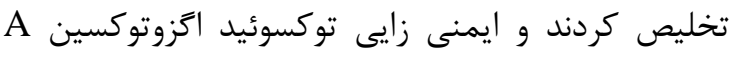

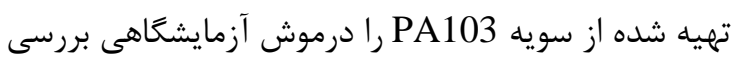

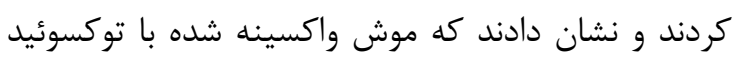

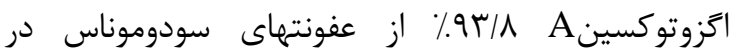

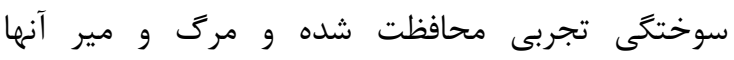

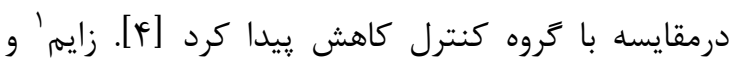

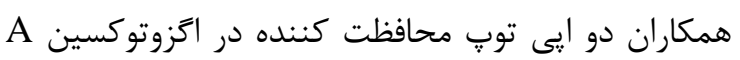

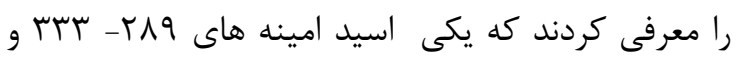

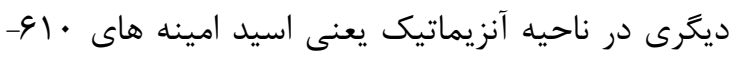

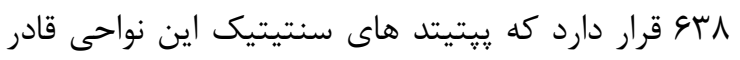
به ايجاد آنتى بادى اختصاصى عليه اكزوتوكسين A شده و در آن خاصيت توكسيك هم وجود ندارد و مطالعه نشان إنئ داد هر دو اين يُتيدها براى اتزوتوكسين A

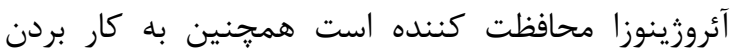

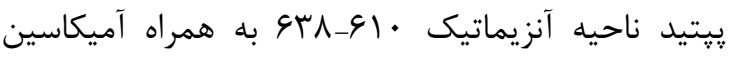

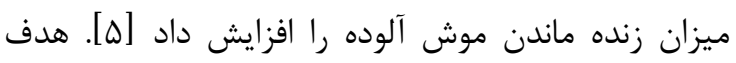

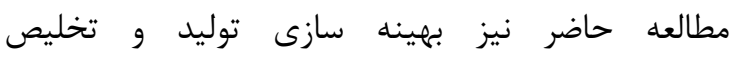

\section{1 -Zaim}

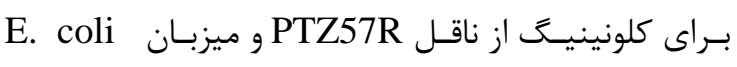

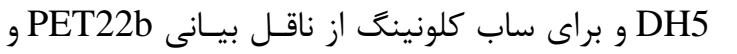

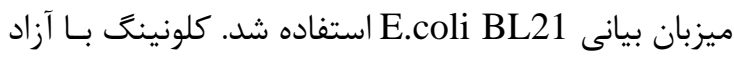

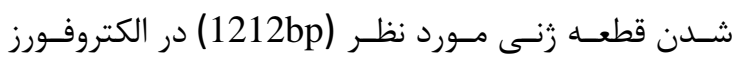
محصول هضم آنزيمى يلاسـميد نوتركيـب و در نهايـت بـا تعيين توالى از طريق شركت MWG تاييد شد (شكل r ).

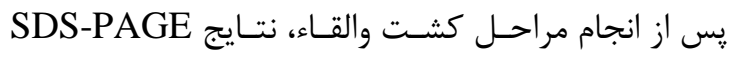

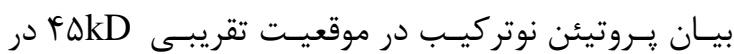

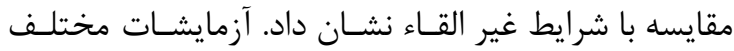

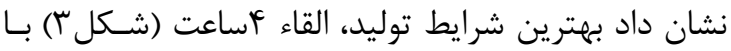

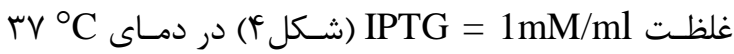
مسى باشـد. سونيكاسـيون و بررسى مـايع رويسى وليـزات

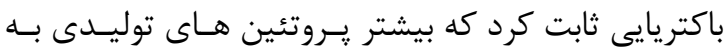

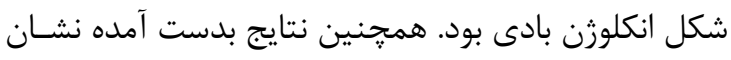

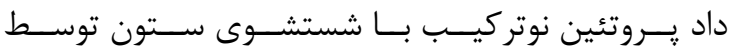

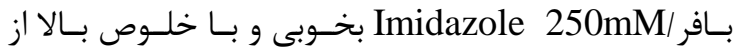
ستون جدا مى شود (شكلها

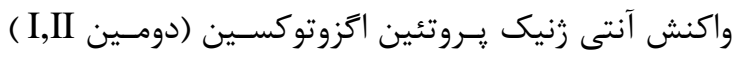
نوتركيب با آنتى بادى اكزوتوكسين A تهيه شده از سيخما در ايمونوبلاتينگ (Product Number P2318 Sigma) به اثبات رسيد همجنين نتايج ايمونوبلاتينگ با اسـتفاده از سرم بيماران مبتلا به عفونت سودوموناس آئروزينوزا نشـان انيان داد يروتئين نوتركيب تخليص شده در اين مطالعه با سـرم اين بيماران بخوبى واكنش نشان مى دهد (شكل 9).

هدف از انجام مطالعه حاضر بررسى امكان توليد اتزوتوكسين A (دومين II II نوتركيب در شرايط بهينه

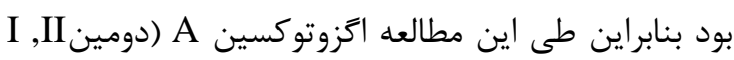
) به صورت نوتركيب توليد، تخليص و ارزيابى كرديد و فاكتورهاى موثر در ميزان بيان اين يروتئين از جمله دماى

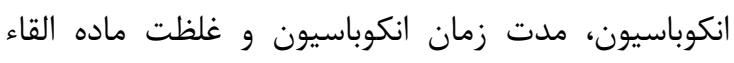
كننده بررسى و بهينه سازى شد. و نتايج نشان داد امكان

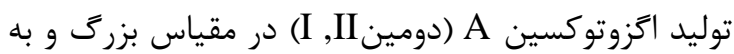

صورت نوتر كيب براى مصارف مختلف وجود دارد.

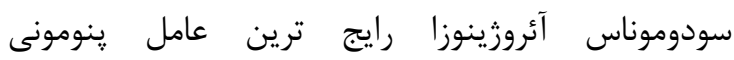
بيمارستانى است. باكتريمى ايجاد شده توسط سودوموناس

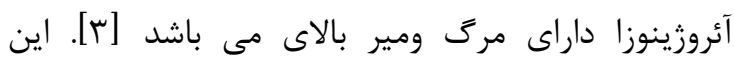


^ץ اسيد امينه از انتهاى كربوكسيلى آن تركيب غير سمى

و نوتركيب از اتزوتوكسين A با خاصيت ايمونوزنيسيته

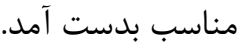

نتيجه تعيين توالى ناقل نوتركيب PTZ57R-ExoA

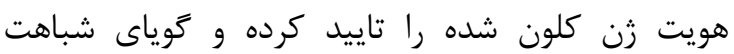

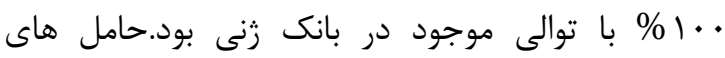

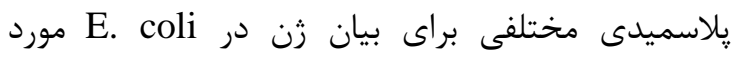

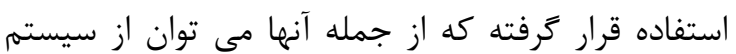
هاى بيانى PQE,PGEX و PET نام برد در سيستم هاى

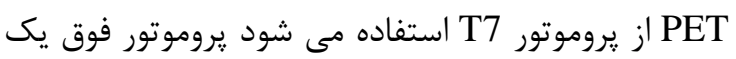

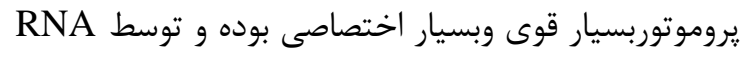

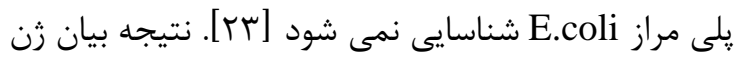
EXOA با واسطه ناقل PET22b توليد يروتئين نوتركيب نداني

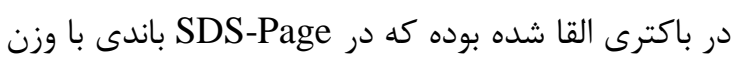

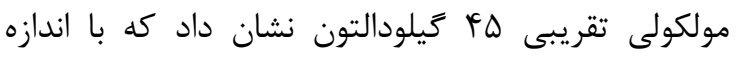
مورد انتظار مطابقت داشت بنابراين اين سيستم، ميزبان

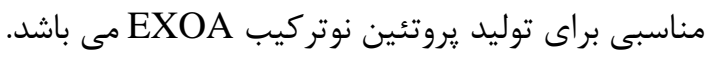

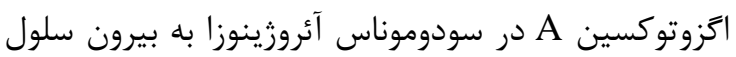
و غشائ خارجى ترشح نمى شود بلكه در فضاى يرى

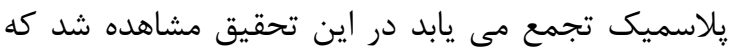

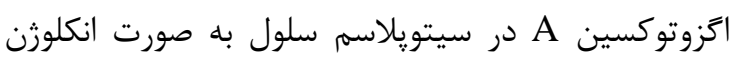

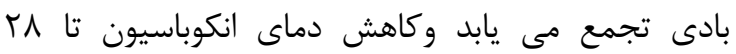
درجه سانتيخراد نيز كمك قابل توجهى به محلول سازى

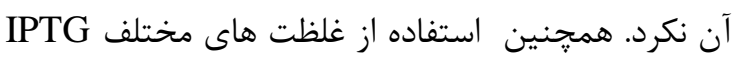
و تغيير مدت القاء تفاوت معنى دارى در افزايش بين بيان

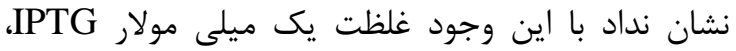

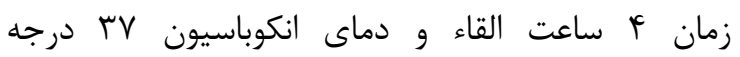
سانتيخراد بهترين شرايط توليد در اين مطالعه بود انون.

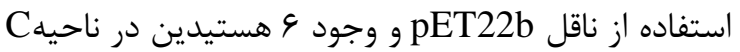

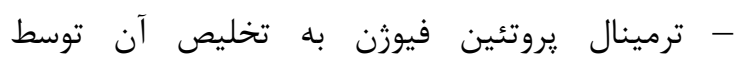

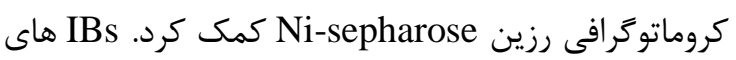
جمع آورى شده در اوره 1 مولار براحتى حل شد اما جداسازى آن از ستون در مراحل تخليص توسط درأ دراديانت

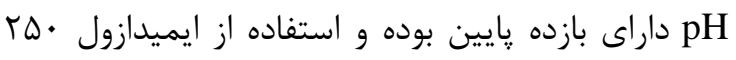

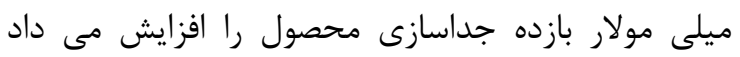

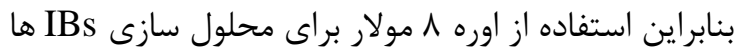

اتزوتوكسين A (دومين I,II) نوتركيب و ارزيابى اوليه آن در آزمايشعاه مى باشد. به علت مشكلات زياد استخراج اتزوتوكسين A و همجنين

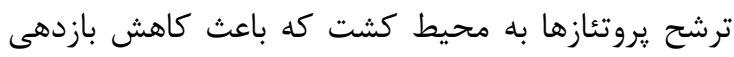
محصول مى شود توليد نوتركيب آن روش مناسبى براى برى برأ بدست آوردن اتزوتوكسين A با كميت و كيفيت بالا مى دي

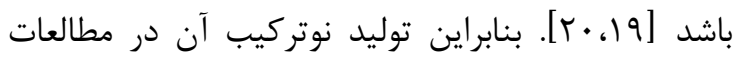
مختلف مورد توجه قرار كرفته است. بيات و همكاران طى نى ني يك مطالعه اقدام به كلونينگ وبيان دومين هاى توكسيك هريك

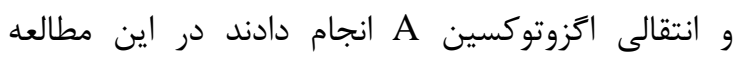
دومين اتصال به رسيتور و دومين انتفال دهنده كلون،

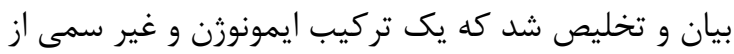
اتزوتوكسين A است اين تركيب داراى ايى توب هاى

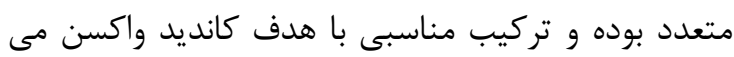

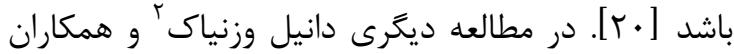

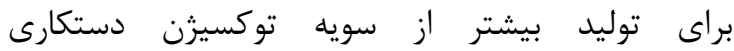

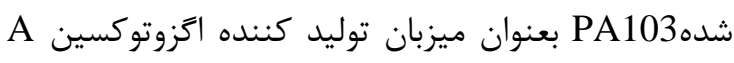

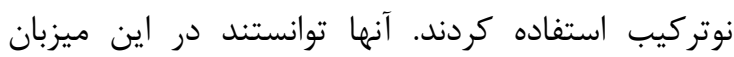
اكزوتوكسين A نوتركيب با فولدينگ طبيعى و با بازده بالا توليد كنند جون اين سويه ميزبان طبيعى توليد اتزوتوكسين A و آنزيم هاى يروتوليتيك شكننده

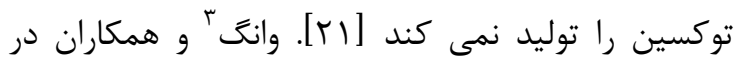

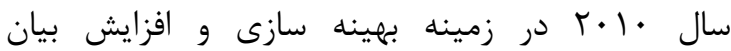

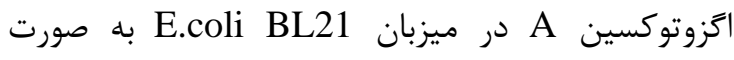
نوتركيب كار كردند و آنها با تغيير كدون ها و كم كردن

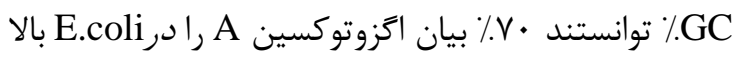

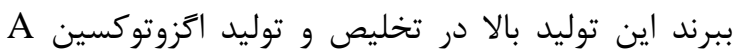

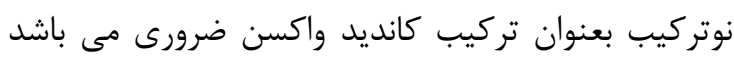

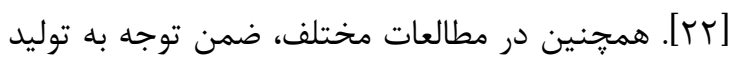
نوتركيب اكزوتوكسين A في تغييراتى در ساختمان آن جهن غير سمى كردن با هدف كانديد واكسن انجام كرفته است

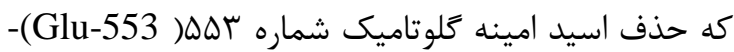

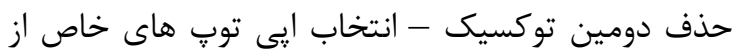

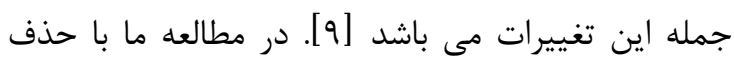

2-Wozniak

3- Wang 


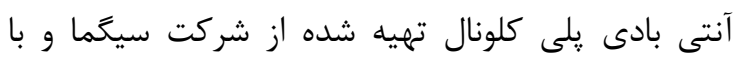

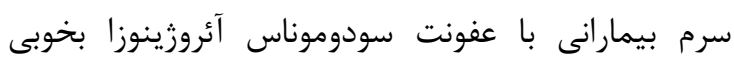

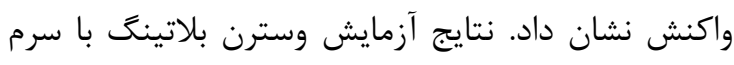

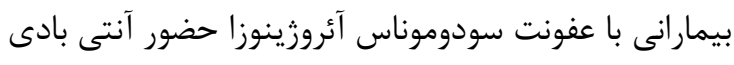

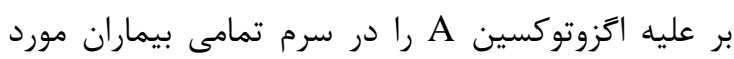

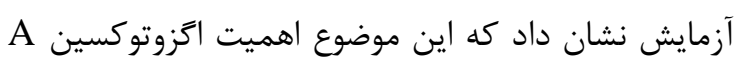

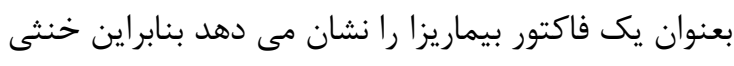
سازى آن در مبارزه با عفونت هاى سودوموناس آئروزينوزا

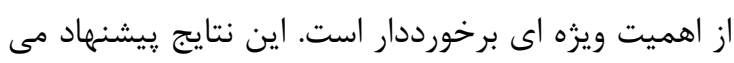
كند يروتئين نوتركيب تهيه شده در اين مطالعه مى تواند

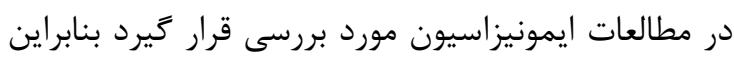
ييشنهاد مى شود اثر آن در ايمو نيزاسيون فعال وغير فعال

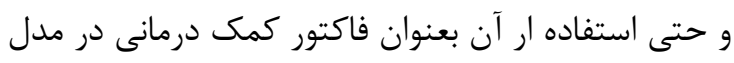
حيوانى مورد بررسى قرار كيرد.

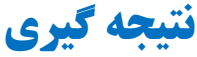

PET22b دومين I,II) نوتركيب در ناقل A داتزوتوكسين

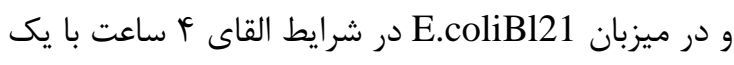

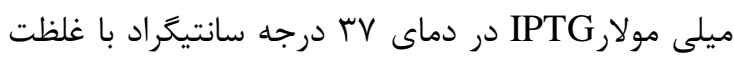
بالا بخوبى بيان مى شود و اين يروتئين مى تواند در دراني

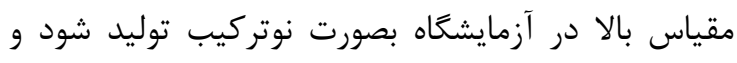

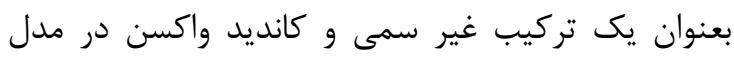
حيوانى مورد بر بعى قرار تيردي

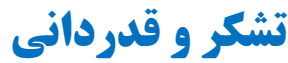

اين مطالعه با حمايت مالى دانشعاه آزاد اسلامى واحد

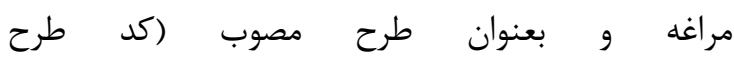

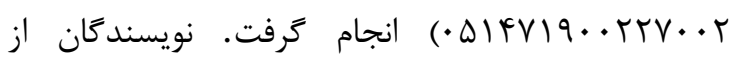

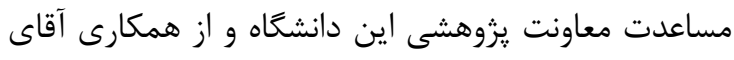
حميد مصطفى زاده، خانم دكتر ليلا رهبر نيا و خانم شيوا عهدى تشكر و قدردانى مى نمايند. 


\section{References}

1. Mesaros N, Nordmann P, Plesiat P,“ et al”, Pseudomonas aeruginosa: resistance and therapeutic options at the turn of the new millennium, Clin Microbiol Infect,2007; 13(6):560-78.

2. Ian Alan Holder, Pseudomonas immunotherapy: a historical overview, Vaccine 2004; 22: 831839.

3. Roger Sordé, Albert Pahissa, Jordi Rello, Management of refractory Pseudomonas aeruginosa infection in cystic fibrosis, Infection and Drug Resistance 2011;4: 31-41.

4. Manafi A, Kohanteb J, Mehrabani D, "et al", Active immunization using exotoxin A confers protection against Pseudomonas aeruginosa infection in a mouse burn model, BMC Microbiol, 2009; Feb 1;9-23.

5. Zaim HS EI, Chopra Ak, pter son j w, Vasil M L, hggers J P, Protection against exotoxin A (ETA) and Pseudomonas aeruginosa infection in mice with ETA-spcific antipeptide antibodies, Infect Immun, 1998 Nov; 66(11):5551-4.

6. Cryz Sj, Fiirer E, Sadoff JC, "et al”, Use of pseudomonas aeruginosa toxin A in the construction of conjugate vaccines and immunotoxins, Clin Infect Dis 1987 9: 644-649.

7. Hertle R, Mrsny R, Fitzgerald D, Dual-Function Vaccine for Pseudomonas aeruginosa: Characterization of Chimeric Exotoxin A-Pilin Protein, Infect Immun 2001; 69(11): 6962-6969.

8. Denis-Mize KS, Price BM, Analysis of immunization with DNA encoding Pseudomonas aeruginosa exotoxin A, FEMS immunol Med Microbiol, 2000 Feb; 27(2):147-54.

9. Chen TY,Shang HF, Recombonant protein composed of pseudomonas exotoxin A, outer membrane proteins I and $\mathrm{F}$ as vaccine against $\mathrm{P}$, aeruginosa infection, Appl Microbiol Biotechnol, 1999 oct; 52(4):524-33.

10. Wolf P, Elsässer-Beile U, Pseudomonas exotoxin A: From virulence factor to anti-cancer agent, Int. J. Med. Microbiol 2009; 299(3):161-176.

11.Tavajjohi Z, Moniri R, Detection of ESBLs and MDR in Pseudomonas aeruginosa in a tertiary-care teaching hospital, Iran J Clin Infect Diseases 2011; 6(1):18-23[Persian].

12. Yousefi S, Nahaei MR, Farajnia S, "et al", Metallo- $\beta$-lactamase-producing Pseudomonas aeruginosa in two Iranian teaching hospitals, their antimicrobial susceptibility and serotypes, J chemotherapy 2011; 23(2):114-116[Persian].

13.Lee S, Park YJ, Kim M,“ et al”,Prevalence of Ambler class A and D $\beta$-lactamases among clinical isolates of Pseudomonas aeruginosa in korea, J antimicrobial chemotherapy 2005; 56:122-127.

14. Merlo CA, Boyle MP, Diener-West M, Marshall BC, Goss CH, Lechtzin N. Incidence and risk factors for multiple antibiotic-resistant Pseudomonas aeruginosa in cystic fibrosis, Chest 2007; 132(2):562-568.

15.Aloush V, Navon-Venezia S, Seigman-Igra Y, Cabili S, Carmeli Y, Multidrug-Resistant Pseudomonas aeruginosa: Risk Factors and Clinical Impact , Antimicrob Agents Chemother,2006; 50(1): 43-48.

16.Breidenstein BE, Fuente-Núñez CDL, Hancock RE, Pseudomonas aeruginosa: all roads lead to resistance,Trends Microbiol 2011; 19(8):419-426.

17.Doring G, Pierb G, Vaccines and immunotherapy against Pseudomonas aeruginosa,Vaccine, 2008, 26:1011-1024.

18.Cryz SJ, Furer E, Que UJ, Synthesis and charactization of a Pseudomonas aeruginosa AlginateToxin A conjugate vaccine, Infect Immun, 1991; 59:1045-50.

19. Keyvani $\mathrm{H}$, ghasemian $\mathrm{H}$, Purification of exotoxin A from pseudomonas aeruginosa, J.Vet.Res 2001; 56(3):33-36[Persian].

20.Bayat A, Kamali A, Zarei A, "et al", Isolation, identification and cloning of transfer domain of exotoxin A from pseudomonas aeruginosa, Kowsar Medical Journal 2010; 15(3): 149-154.

21.Wozniak D J, Han X Y and Galloway D R, Construction and use of a nontoxigenic strain of Pseudomonas aeruginosa for the production of recombinant exotoxin A.Appl. Environ. Microbiol 1995; 61(5):1739-1746. 


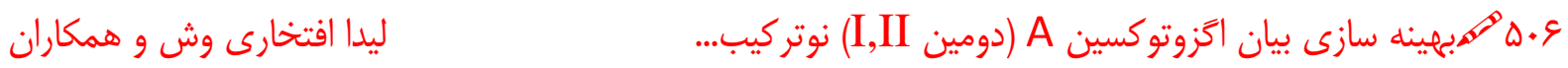

22.Wang X, Li X, Zhang Z, Shen X, Zhong F, Codonoptimization enhances secretory expression of Pseudomonas aeruginosa exotoxin A in E, coli.Protein Expression and Purification 2010; 72(1): 101106.

23.Farajnia S, Hassanpour R, Lotfipour F, Cloning and expression of human IL-11 in E. coli. Pharma.Scie 2010; 15(4):353-359[Persian]. 


\title{
Optimization of expression and in vitro characteristics evaluation of Pseudomonas aeruginosa recombinant exotoxin A (domains I and II)
}

\author{
Eftekharivash L1 Farajnia $S^{2} \quad$ Najar Peerayeh $S h^{3} \quad$ Tanomand $A^{4} *$
}

${ }^{1}$ Instructor of Microbiology, Dept of Mirobiology, Islamic Azad University- Mragheh branch, Maragheh, Iran.

${ }^{2}$ Associate Professor of Biotechnology, Biotechnology Research Center, Tabriz University of Medical Sciences, Tabriz, Iran

${ }^{3}$ Associate Professor of Bacteriology, Dept of Bacteriology Faculty of Medical sciences, Tarbiat Modares University, Tehran, Iran.

${ }^{4}$ Assistant Professor, Dept. of Laboratory Sciences, Maragheh Faculty of Medical Sciences, Maragheh university of Medical Sciences, Maragheh, Iran

*Corresponding Author: Assistant Professor, Dept. of Laboratory Sciences, Maragheh Faculty of Medical Sciences, Maragheh university of Medical Sciences, Maragheh, Iran Email: tanomanda@yahoo.com

\section{Abstract}

Background \& Objectives: P. aeruginosa exotoxin A plays an important role in virulence of the bacterium and its neutralization can abolish the P. aeruginosa pathogenicity. Therefore, we showed optimization of recombinant production and in vitro antigenic characteristics evaluation of exotoxin A (domains I and II) as a vaccine candidate.

Material \& Methods: In this study, after DNA extraction and amplification with PCR, gene fragment was ligated to Pet $22 b$ vector and transferred to E.coli BL21. The protein expression was evaluated by SDS-PAGE method. The Ni-NTA affinity chromatography was used for recombinant protein purification. Then, the reactivity of recombinant exotoxin A with anti-exotoxin A antibody (Sigma) and sera from $P$. aeruginosa infected patients was evaluated by western blotting method.

Results: Sequencing of cloned gene showed that the sequence of exoA I-II gene was in accordance with exoA I-II from P. aeruginosa PAOI. SDS-PAGE analysis indicated that expression of recombinant protein with a molecular weight of $45 \mathrm{kD}$. The results showed, 4 hours induction with $I P T G=0.5 \mathrm{mM} / \mathrm{m}$ in $28^{\circ} \mathrm{C}$ is optimum condition for expression protein. Western blot analysis of the purified protein demonstrated that ExoA I-II could be recognized by antibody against native exotoxin $A$ and the serum of patients with $P$. aeruginosa infection.

Conclusion: These results suggest that recombinant exoA I-II protein can be produced in the laboratory and this system can be used for large scale production of this protein for subsequent immunological studies.

Key words: Pseudomonas aeruginosa - vaccine candidate - exotoxin Arecombinant vaccine 